\title{
In vitro Propagation of Adenia hondala (Gaertn.) de Wilde
}

\author{
Bindu T K, Sheema Dharmapal P, P.S.Udayan
}

PG Department of Botany \& Research Centre, Sree Krishna College, Guruvayur, Ariyannur P O,Thrissur-680102, Kerala, India Corresponding Author: bindutksahadevan@gmail.com

\begin{abstract}
Adenia hondala (Gaertn.) de Wilde belonging to the family Passifloraceae is a perennial climbing herb with potential medicinal value. The possibility of in vitro clonal propagation of Adenia hondala was investigated by the use of nodal explants cultured on Murashige and Skoog (MS) medium supplemented with different concentrations and combinations of BAP and KN. Optimum treatment was the combination of $1 \mathrm{mg} . \mathrm{L}^{-1} \mathrm{BAP}$ and $0.5 \mathrm{mg} . \mathrm{L}^{-1} \mathrm{KN}$ that enhanced percent response of explants and the number of multiple shoots per explants. An average of 10.23 shoots per explants was resulted after 32 days of culture. In vitro shoots were elongated in MS medium supplemented with I $m g . L^{-1} K N$. Half strength MS medium supplemented with 1 $m g . L^{-1} I B A$ was found to be the best medium for rooting. The rooted plantlets were gradually acclimated ex vitro in mist chamber and successfully established under field conditions with high survival rate.
\end{abstract}

Keywords - Adenia hondala, in vitro, multiple shoots, nodal segments.

\section{INTRODUCTION}

Adenia hondala belonging to the family Passifloraceae is found in the forests of Western Ghats. It has been red listed as vulnerable in South India. A. hondala is a perennial climber with tuberous roots, simple tendrils, simple and lobed leaves and circular glands between lobes of leaves. The monoecious flowers have oblong petals, 5 stamens, globular ovary and a trifid stigma. The tuber powder is used to treat cough and it increase lactation in nursing mother. The extract of tuber is used to cure intermittent fever, Anonymous, (1999) and the roots are used for the treatment of skin troubles, Anonymous, (2003).

Ayurveda is a system of Medicine with historical roots in Indian Subcontinent. 'Vidari', an Ayurvedic drug is an ingredient of more than 50 Ayurvedic formulations like Chyavanaprash and its annual requirement is about 500 1000 Metric Tonnes, Sulaiman et al., ( 2014). Ayurveda correlates 'vidari' to tubers of Pueraria tuberosa (Roxb. Ex Willd.) DC (Fabaceae) and Kshiravidari to Ipomoea mauritiana Jacq. (Convolvulaceae). However, in Ayurvedic www.ijeab.com
Pharmacopoeia both these species are attributed similar properties and are substituted by each other, Venkatasubramanian et al., (2009). Apart from these, tubers of Adenia hondala (Passifloraceae) and the pith of Cycas circinalis L. (Cycadaceae) are also traded as 'vidari' ,Ved and Goraya, (2008). 'Vidari' is used as aphrodisiac, cardiotonic, diuretic and refrigerant, Chopra et al., (1992). In traditional and folklore systems, 'vidari' has been used as a tonic, rejuvenator and galactogogue, Mithila et al., (2014). It is reported that use of 'vidari' is beneficial in persons suffering from or prone to diabetes and coronary disease problems, Sulaiman et al., ( 2014).

Indiscriminate collection, poor seed set and seed germination resulted in the disappearance of this plant from wild habitats. The reason for the diminishing number of $A$. hondala could be the dwindling forests due to excessive urbanization. Having established its potential as a medicinal plant there is a great necessity for large scale multiplication of this plant which is rapid, simple and genetically stable. In vitro protocols serve as a viable tool for conservation and propagation of germplasm, especially of endangered and threatened plants. There is a single report on in vitro propagation of this plant species (A.hondala) which focuses on in vitro organogenesis and somatic embryogenesis. The present experiment was conducted to develop a successful protocol for rapid clonal propagation of A.hondala through the culture of nodal explants.

\section{MATERIALS AND METHODS}

\subsection{Plant sample and experiment design}

Stem cuttings with four to six nodes were collected from three months old $A$. hondala plant. The stem was cut into single node pieces ( 2 to $3 \mathrm{~cm}$ length) and was washed in running tap water for 10 minutes. The nodal explants were then immersed in Bavistin solution (15 g. $\left.\mathrm{L}^{-1}\right)$ for 3 minutes with Cefotaxime (200 mg. $\mathrm{L}^{-1}$ ) and Tetracycline (200 mg.L$\left.{ }^{1}\right)$. After distilled water wash, the explants were sterilized in $1 \%$ mercuric chloride solution for three minutes followed by several rinses with double distilled water. The $\mathrm{pH}$ of the medium was adjusted to 5.8 before autoclaving at $15 \mathrm{psi}$

Page | 175 
pressure and $121^{\circ} \mathrm{C}$ temperature for 15 minutes. All these culture vials were incubated in plant growth room at $25 \pm 2^{\circ} \mathrm{C}$ under $16 / 8$ hour photoperiod with $50 \mu \mathrm{mol} \mathrm{m-}{ }^{2} \mathrm{~s}^{-1}$ light intensity supplied by cool white fluorescent lamps and $60 \pm 65 \%$ relative humidity. The nodal explants were then inoculated into MS media (Murashige and Skoog, 1962) supplemented with $3 \%$ (w/v) sucrose and $0.8 \%(w / v)$ agar. The shoot bud initiation and multiple shoot induction were studied by inoculating the explants on MS media supplemented with 6- Benzylaminopurine -BAP $(0.25,0.5$, $\left.1.0,2.0 \mathrm{mg} . \mathrm{L}^{-1}\right)$ either alone or in combination with Kinetin$\mathrm{KN}\left(0.25,0.5,1.0,2.0 \mathrm{mg} . \mathrm{L}^{-1}\right)$. Subcultures were carried out at an interval of 14 days. The proliferation rate for each of the treatment was observed. Same media compositions were used to study shoot elongation. During elongation, the length of shoot and the number of nodes were observed and recorded. Half strength and full strength MS media with $\left(0.25,0.5,1.0 \mathrm{mg} . \mathrm{L}^{-1}\right)$ or without Indole Butyric Acid- IBA were experimented for in vitro rooting. Percentage of root induction, root length and root number were the parameters recorded for each treatment. The rooted shoots were taken out from the culture bottles and washed thoroughly with running tap water to remove traces of medium. These plants were transferred to plastic pots containing a mixture of soil and sand. Almost all rooted plants were acclimated and transferred to field conditions.

\subsection{Statistical analysis}

All experiments were performed with three replications, having 30 samples each. The effect of various treatments on selected growth parameters was measured quantitatively and statistically tested using analysis of variance (ANOVA) using SPSS (Statistical Package for the Social Sciences) version 11.0. The significance of the mean values of various treatments was assessed by Duncan's New Multiple Range Test (DMRT) at $\mathrm{p}<0.05$.

\section{RESULTS}

3.1 Effect of BAP and KN on multiple shoot induction and shoot proliferation from nodal explants

Cultures without any growth regulators were taken as control. No shoot induction was observed in control media. The effect of cytokinis on multiple shoot induction was experimented by culturing the nodal explants on MS medium supplemented with BAP and KN either alone or in different combinations. It was observed that, for the same concentration of BAP and KN tested $(0.25,0.5,1.0,2.0$ mg. $\left.\mathrm{L}^{-1}\right)$, percentage of explants showing shoot induction decreased (Table 1) on KN supplemented (75- 78\%) media than the media with BAP (81- 83\%). Among various concentrations and combinations, best results were recorded on medium containing $1 \mathrm{mg} . \mathrm{L}^{-1} \mathrm{BAP}$ and $0.5 \mathrm{mg} . \mathrm{L}^{-1} \mathrm{KN}$ noticed $87 \%$ of explants proliferated within 7 days (Table 1).This particular combination of growth regulators regenerated 10.23 \pm 0.40 shoots, (Fig 1) which was found to be the single optimum treatment that promoted highest number of multiple shoots within 32days. MS medium with different combinations of BAP and $\mathrm{KN}$ favoured comparatively high multiple shoot regeneration than the treatments with BAP or $\mathrm{KN}$ alone. Combinations of BAP (1.0 mg. $\left.\mathrm{L}^{-1}\right)$ with $\mathrm{KN}\left(0.25,0.5 \mathrm{mg} . \mathrm{L}^{-1}\right)$ significantly increased the shoot number as compared to other treatments with BAP and $\mathrm{KN}$ alone (Table 2). In the present study, increased concentrations of BAP (2 mg.. $\left.\mathrm{L}^{-1}\right)$ adversely affected the shoot multiplication rate.

\subsection{Effect of KN on shoot elongation}

Same media composition as that of the shoot induction media were experimented for shoot elongation. Shoots obtained from KN supplemented media were significantly longer among all treatments including their combinations (Table 2). Among all the concentrations and combinations of growth regulators used, MS with $1.0 \mathrm{mg} . \mathrm{L}^{-1} \mathrm{KN}$ showed better result for shoot elongation after 12 days of sub culturing with an average length of $4.87 \pm 0.15 \mathrm{~cm}$ and an optimum number of $4.10 \pm 0.40$ nodes per explants. In the present study, length of the shoots were shorter in BAP as compared to $\mathrm{KN}$ either alone or in their combination (Table $3)$. Shoots of $\mathrm{KN}$ supplemented media were significantly longer among all cytokinin treatment. The presence of $\mathrm{KN}$ in the medium allowed the in vitro shoots to elongate where the morphogenetic response was lower in lower concentrations $\left(0.25,0.5 \mathrm{mg} . \mathrm{L}^{-1}\right)$ as compared to higher concentration (1.0 mg. $\left.\mathrm{L}^{-1}\right)$. Moreover higher concentrations of BAP (2 mg. $\left.\mathrm{L}^{-1}\right)$ inhibited the shoot length compared to its lower concentrations $\left(0.25,0.5,1.0 \mathrm{mg} . \mathrm{L}^{-1}\right)$ with or without KN.

\subsection{Effect of Media and IBA on rooting}

To induce rooting, in vitro shoots were transferred to full strength and half strength MS media with $(0.25,0.5,0.1$ mg. $\left.\mathrm{L}^{-1}\right)$ or without IBA. The effects of media and IBA treatment on root formation from in vitro shoots were summarized on Table 4. The inclusion of IBA in the rooting media increased the root number. It was observed that half strength MS supplemented with $1.0 \mathrm{mg} . \mathrm{L}^{-1}$ IBA showed highest percentage of root induction $(83.00 \pm 0.50)$. Half strength MS media supplemented with IBA (1.0 mg.L $\left.{ }^{-1}\right)$ was optimum in inducing an average number of roots $(3.83$ \pm 0.35 ) reaching up to length $4.43 \pm 0.15 \mathrm{~cm}$ within two 
weeks of culture. As compared to half strength MS, full

strength MS supplemented with IBA resulted in a significant decrease in the percentage of root induction, number of roots and length of roots.

Table.1: Effect of BAP and KN on multiple shoot induction using nodal explants

\begin{tabular}{|c|c|c|c|c|}
\hline \multirow{2}{*}{ Treatments } & \multicolumn{2}{|c|}{ MS + Growth regulators } & $\begin{array}{c}\text { \% of explants showing } \\
\text { shoot induction }\end{array}$ & $\begin{array}{c}\text { Number of days for shoot } \\
\text { induction }\end{array}$ \\
\cline { 2 - 5 } & BAP $\left(\mathrm{mg} \cdot \mathrm{L}^{-1}\right)$ & $\mathrm{KN}\left(\mathrm{mg} \cdot \mathrm{L}^{-1}\right)$ & $00.000^{\mathrm{i}}$ & $00.000^{\mathrm{g}}$ \\
\hline $\mathrm{T}_{0}$ & 0 & 0 & $83.36 \pm 0.41^{\mathrm{c}}$ & $8.20 \pm 0.26^{\mathrm{d}}$ \\
\hline $\mathrm{T}_{1}$ & 0.25 & 0 & $82.33 \pm 0.47^{\mathrm{d}}$ & $8.43 \pm 0.20^{\mathrm{d}}$ \\
\hline $\mathrm{T}_{2}$ & 0.5 & 0 & $81.26 \pm 0.20^{\mathrm{e}}$ & $8.90 \pm 0.10^{\mathrm{c}}$ \\
\hline $\mathrm{T}_{3}$ & 1 & 0 & $85.73 \pm 0.61^{\mathrm{b}}$ & $7.67 \pm 0.20^{\mathrm{e}}$ \\
\hline $\mathrm{T}_{4}$ & 1 & 0.25 & $87.05 \pm 0.10^{\mathrm{a}}$ & $6.90 \pm 0.26^{\mathrm{f}}$ \\
\hline $\mathrm{T}_{5}$ & 1 & 0.5 & $80.57 \pm 0.14^{\mathrm{f}}$ & $8.86 \pm 0.05^{\mathrm{c}}$ \\
\hline $\mathrm{T}_{6}$ & 2 & 0 & $78.37 \pm 0.40^{\mathrm{g}}$ & $9.26 \pm 0.24^{\mathrm{b}}$ \\
\hline $\mathrm{T}_{7}$ & 0 & 0.25 & $77.73 \pm 0.25^{\mathrm{g}}$ & $9.46 \pm 0.05^{\mathrm{ab}}$ \\
\hline $\mathrm{T}_{8}$ & 0 & 0.5 & $75.90 \pm 0.62^{\mathrm{h}}$ & $9.77 \pm 0.01^{\mathrm{a}}$ \\
\hline $\mathrm{T}_{9}$ & 0 & 1.0 & $75.50 \pm 0.34^{\mathrm{h}}$ & $9.76 \pm 0.14^{\mathrm{a}}$ \\
\hline $\mathrm{T}_{10}$ & 0 & 2.0 & & \\
\hline
\end{tabular}

Level of significance was measured at $\mathrm{p}<0.05$. Column values with same superscript are not differing significantly $(\mathrm{P}>0.05)$

Table.2: Effect of BAP and KN on shoot proliferation after 32 days of culture.

\begin{tabular}{|c|c|c|c|}
\hline \multirow[t]{2}{*}{ Treatments } & \multicolumn{2}{|c|}{ MS + Growth regulators } & \multirow{2}{*}{$\begin{array}{c}\text { Number of multiple shoots } \\
\text { per explant }\end{array}$} \\
\hline & BAP (mg.L $\left.{ }^{-1}\right)$ & $\mathrm{KN}\left(\mathrm{mg} . \mathrm{L}^{-1}\right)$ & \\
\hline $\mathrm{T}_{0}$ & 0 & 0 & $00.000^{\mathrm{g}}$ \\
\hline $\mathrm{T}_{1}$ & 0.25 & 0 & $3.50 \pm 0.30^{\mathrm{e}}$ \\
\hline $\mathrm{T}_{2}$ & 0.5 & 0 & $3.97 \pm 0.21^{\mathrm{de}}$ \\
\hline $\mathrm{T}_{3}$ & 1 & 0 & $4.67 \pm 0.25^{\mathrm{c}}$ \\
\hline $\mathrm{T}_{4}$ & 1 & 0.25 & $5.93 \pm 0.30^{\mathrm{b}}$ \\
\hline $\mathrm{T}_{5}$ & 1 & 0.5 & $10.23 \pm 0.40^{\mathrm{a}}$ \\
\hline $\mathrm{T}_{6}$ & 2 & 0 & $3.40 \pm 0.36^{\mathrm{e}}$ \\
\hline $\mathrm{T}_{7}$ & 0 & 0.25 & $2.40 \pm 0.40^{\mathrm{f}}$ \\
\hline $\mathrm{T}_{8}$ & 0 & 0.5 & $3.87 \pm 0.11^{\mathrm{de}}$ \\
\hline $\mathrm{T}_{9}$ & 0 & 1.0 & $4.23 \pm 0.49^{\mathrm{cd}}$ \\
\hline $\mathrm{T}_{10}$ & 0 & 2.0 & $2.17 \pm 0.50^{f}$ \\
\hline
\end{tabular}

Level of significance was measured at $\mathrm{p}<0.05$. Column values with same superscript are not differing significantly $(\mathrm{P}>0.05)$

Table.3: Effect of $K N$ on shoot elongation after 12 days of culture

\begin{tabular}{|c|c|c|c|c|}
\hline \multirow{2}{*}{ Treatments } & \multicolumn{2}{|c|}{ MS + Growth regulators } & \multirow{2}{*}{ Shoot length $(\mathrm{cm})$} & \multirow[b]{2}{*}{ Number of nodes } \\
\hline & BAP (mg.L $\left.\mathrm{L}^{-1}\right)$ & $\mathrm{KN}\left(\mathrm{mg} \cdot \mathrm{L}^{-1}\right)$ & & \\
\hline $\mathrm{T}_{0}$ & 0 & 0 & $00.000^{\mathrm{g}}$ & $00.000^{\mathrm{d}}$ \\
\hline $\mathrm{T}_{1}$ & 0.25 & 0 & $2.50 \pm 0.10^{\mathrm{e}}$ & $2.20 \pm 0.30^{\mathrm{b}}$ \\
\hline $\mathrm{T}_{2}$ & 0.5 & 0 & $2.53 \pm 0.37^{\mathrm{e}}$ & $2.30 \pm 0.46^{\mathrm{b}}$ \\
\hline $\mathrm{T}_{3}$ & 1 & 0 & $2.80 \pm 0.20^{\mathrm{de}}$ & $2.23 \pm 0.51^{\mathrm{b}}$ \\
\hline $\mathrm{T}_{4}$ & 1 & 0.25 & $3.03 \pm 0.35^{\mathrm{d}}$ & $2.80 \pm 0.40^{\mathrm{b}}$ \\
\hline $\mathrm{T}_{5}$ & 1 & 0.5 & $3.53 \pm 0.40^{\mathrm{bc}}$ & $2.50 \pm 0.40^{\mathrm{b}}$ \\
\hline $\mathrm{T}_{6}$ & 2 & 0 & $2.06 \pm 0.15^{f}$ & $1.20 \pm 0.10^{\mathrm{c}}$ \\
\hline $\mathrm{T}_{7}$ & 0 & 0.25 & $3.23 \pm 0.25^{\mathrm{cd}}$ & $2.77 \pm 0.25^{\mathrm{b}}$ \\
\hline $\mathrm{T}_{8}$ & 0 & 0.5 & $3.87 \pm 0.06^{\mathrm{b}}$ & $3.50 \pm 0.36^{\mathrm{a}}$ \\
\hline
\end{tabular}




\begin{tabular}{|c|c|c|c|c|}
\hline \multirow{2}{*}{ Treatments } & \multicolumn{2}{|c|}{ MS + Growth regulators } & \multirow{2}{*}{ Shoot length(cm) } & Number of nodes \\
\cline { 2 - 5 } & BAP $\left({\left.\mathrm{mg} . \mathrm{L}^{-1}\right)}^{2}\right.$ & $\mathrm{KN}\left(\mathrm{mg} . \mathrm{L}^{-1}\right)$ & $4.87 \pm 0.15^{\mathrm{a}}$ & $4.10 \pm 0.40^{\mathrm{a}}$ \\
\hline $\mathrm{T}_{9}$ & 0 & 1.0 & $3.06 \pm 0.20^{\mathrm{d}}$ & $3.63 \pm 0.31^{\mathrm{a}}$ \\
\hline $\mathrm{T}_{10}$ & 0 & 2.0 & \\
\hline
\end{tabular}

Level of significance was measured at $\mathrm{p}<0.05$. Column values with same superscript are not differing significantly $(\mathrm{P}>0.05)$

Table.4: Effect of media and IBA on in vitro rooting.

\begin{tabular}{|c|c|c|c|c|c|}
\hline Treatments & $\begin{array}{c}\text { Media } \\
\text { strength }\end{array}$ & $\begin{array}{c}\text { IBA } \\
\left(\mathrm{mg} \cdot \mathrm{L}^{-1}\right)\end{array}$ & $\%$ of root induction & Root number & $\begin{array}{l}\text { Root length } \\
\text { (cm) }\end{array}$ \\
\hline $\mathrm{T}_{0}$ & \multirow{4}{*}{$\begin{array}{c}\text { Half strength } \\
\text { MS }\end{array}$} & 0 & $51.03 \pm 0.47^{\mathrm{d}}$ & $1.27 \pm 0.35^{\mathrm{d}}$ & $0.90 \pm 0.26^{\mathrm{d}}$ \\
\hline $\mathrm{T}_{1}$ & & 0.25 & $66.00 \pm 1.00^{c}$ & $1.80 \pm 0.36^{\mathrm{c}}$ & $1.83 \pm 0.42^{\mathrm{c}}$ \\
\hline $\mathrm{T}_{2}$ & & 0.5 & $71.80 \pm 0.80^{\mathrm{b}}$ & $2.80 \pm 0.10^{\mathrm{b}}$ & $2.53 \pm 0.29^{b}$ \\
\hline $\mathrm{T}_{3}$ & & 1 & $83.00 \pm 0.50^{\mathrm{a}}$ & $3.83 \pm 0.35^{\mathrm{a}}$ & $4.43 \pm 0.15^{\mathrm{a}}$ \\
\hline $\mathrm{T}_{0}$ & \multirow{4}{*}{$\begin{array}{c}\text { Full } \\
\text { strength } \\
\text { MS }\end{array}$} & 0 & $40.5 \pm 0.50^{d}$ & $0.83 \pm 0.35^{\mathrm{c}}$ & $0.90 \pm 0.40^{b}$ \\
\hline $\mathrm{T}_{1}$ & & 0.25 & $51.63 \pm 0.20^{c}$ & $0.93 \pm 0.41^{\mathrm{c}}$ & $0.83 \pm 0.20^{b}$ \\
\hline $\mathrm{T}_{2}$ & & 0.5 & $61.00 \pm 1.00^{b}$ & $1.63 \pm 0.05^{b}$ & $1.53 \pm 0.25^{\mathrm{a}}$ \\
\hline $\mathrm{T}_{3}$ & & 1 & $65.9 \pm 0.65^{a}$ & $2.40 \pm 0.10^{\mathrm{a}}$ & $1.93 \pm 0.37^{\mathrm{a}}$ \\
\hline
\end{tabular}

Level of significance was measured at $\mathrm{p}<0.05$. Column values with same superscript are not differing significantly $(\mathrm{P}>0.05)$ 

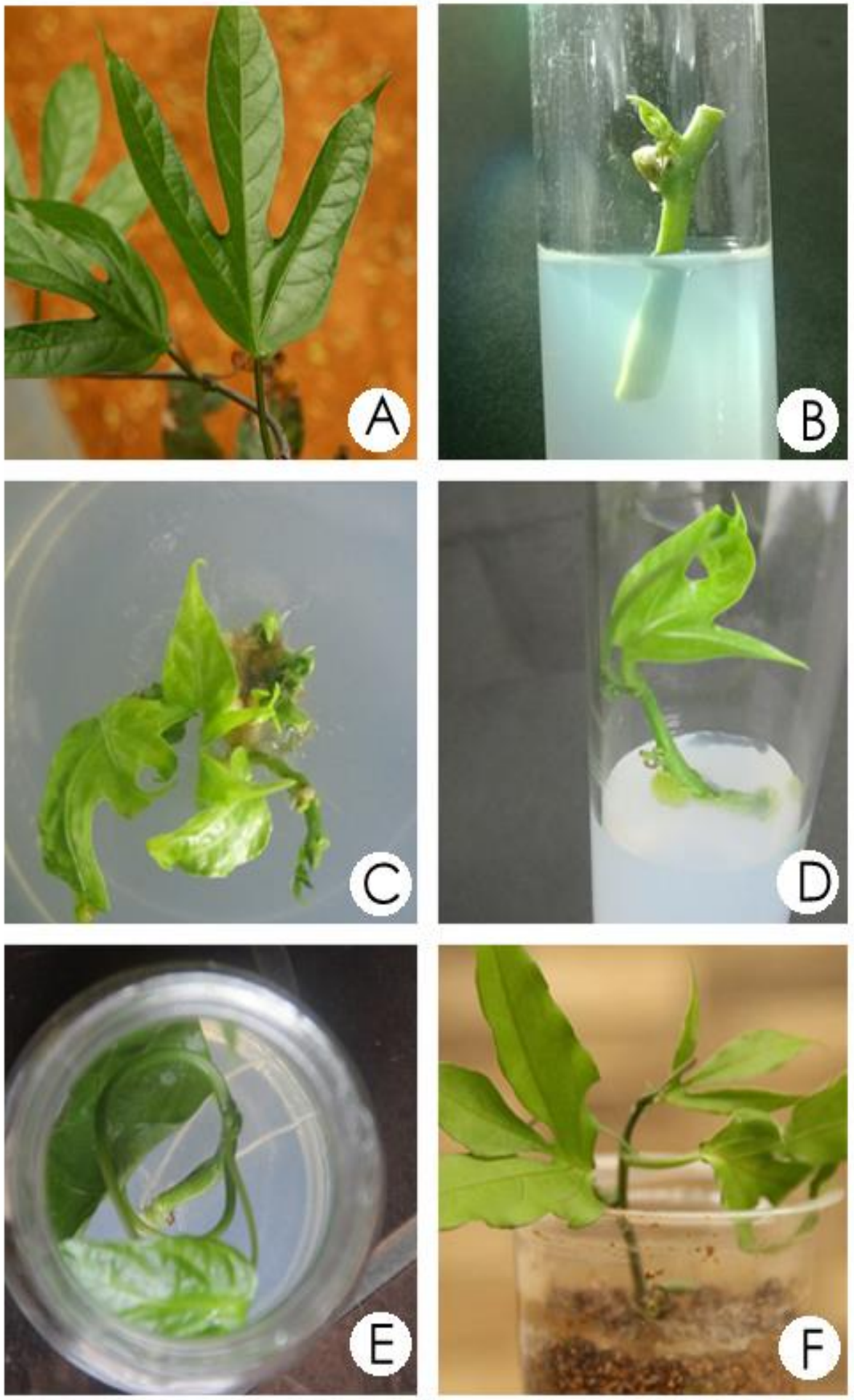

Figure.1.Micropropagation of Adenia hondala.A, Habit of Adenia hondala.: B, Shoot bud initiation from nodal segments in MS medium supplemented with BAP $1 \mathrm{mg} . \mathrm{L}-1+\mathrm{KN} 0.5 \mathrm{mg} \cdot \mathrm{L}-1$ : C, Mul tiple shoot induction from nodal segments in MS supplemented with BAP 1 mg.L-1 + KN 0.5 mg.L-1: D, Shoot elongation in MS supplemented with KN $1 \mathrm{mg} . \mathrm{L}-1$ : E, Rooting in half MS basal media with $1 \mathrm{mg}$.L-1 IBA: F, Hardened in vitro regenerated plant of Adenia hondala after acclimatisation 


\section{DISCUSSION}

Cytokinins have major role on plant development, such as the regulation of shoot induction, shoot multiplication and promotion of cell division, Mok and Mok, (2001). In the present study various concentrations of $\mathrm{BAP}$ and $\mathrm{KN}$ induced significant differences on shoot induction percentage, number of shoots per explants and shoot length. It was observed that the percentage of shoot emergence per explants increased on media with decreased concentrations of cytokinin. These findings are in line with the findings of Reddy and Saritha, (2013). The synergistic effect of BAP and $\mathrm{KN}$ produced high rate of shoot multiplication. The results are in accordance with Mehdi et al., (2014); Shirin and Rana, (2007) and Saha et al., (2007). BAP enhanced in vitro shoot induction and proliferation of many medicinal plant species (Lakshimi and Mythili, 2003) which is in conformity with the results of the present study. BAP is more effective on shoot induction and multiplication and less effective on shoot elongation as compared to $\mathrm{KN}$. These results are in conformity with those of Mehdi et al., (2014) and Sharma et al., (1993). KN treatment significantly affected on increasing the shoot length and number of nodes as compared to any other concentration or combination of BAP either alone or with KN. The stimulatory effect of $\mathrm{KN}$ on shoot elongation was reported by Saha et al., (2007). In the present experiment, optimum response for rooting resulted on half strength MS media with $1 \mathrm{mg} . \mathrm{L}^{-1}$ IBA than full strength MS media with same hormone concentrations. It has been reported, Zayona et al., (2014) half MS supplemented with auxin enhanced the number of rooted plants in micropropagation of Paulownia elongata. The number and length of roots was found to be increased on half strength MS with or without IBA than full strength MS. These results are in accordance with Shekhawat et al., (2015) and Lattoo et al., (2006).

\section{CONCLUSION}

In vitro propagation through nodal explants of A.hondala is an easy and economic way for obtaining large number of consistently uniform plants. Present protocol holds tremendous potential to select, multiply and conserve this genotypes, which are a potential resource of medicinally important constituents and it reduce the dependence on the natural habitat for the supply of raw drugs.

\section{ACKNOWLEDGEMENTS}

The authors are thankful to Dr. G. Jayakrishnan, Head of the Department of Botany, Sree Krishna College, Guruvayur and Dr. E.M. Muraleedharan, Scientist, Kerala
Forest Research Institute (KFRI), Peechi for providing all the necessary facilities and encouragement during the work.

\section{REFERENCES}

[1] Anonymous 1999. AMRUTH Vol. 3 Issue 5, FRLHT, Bangalore.

[2] Anonymous 2003. The Wealth of India: Raw Materials Vol. 1: Publications and Information Directorate, CSIR, New Delhi.P 75.

[3] Chopra, R.N., Nayar, S. L. and Chopra I. C. 1992. Glossary of Indian Medicinal Plants. Council of Scientific and Industrial Research (CSIR). New Delhi: p. 142.

[4] Lakshimi, M. and Mythili, S. 2003. Somatic embryogenesis and regeneration of callus cultures of Kaempferia galanga -A medicinal plant. $J$ Med Aromat Plant Sci, 25(4): 947-51.

[5] Lattoo, S. K., Bamotra, S., Sapru Dhar, R., Khan, S. and Dhar, A. K. 2006. Rapid plant regeneration and analysis of genetic fidelity of in vitro derived plants of Chlorophytum arundinaceum Baker-An endangered medicinal herb. Plant Cell Rep, 25: 499-506.

[6] Mehdi, F. A., Maheran, A. A., Nurashikin, K. and Ismanizan, I. 2014. Effect of cytokinin types, concentrations and their interactions on in vitro shoot regeneration of Chlorophytum borivilianum Sant. \& Fernandez. Electron J Biotechnol, 17: 275-279.

[7] Mithila V. A. and Azizahmed, I. A. 2014. Phytochemical evaluation of churna of vidari (Pueraria tuberosa Roxb.). I J Ayurveda and Holistic Medicine, 2: 11-17.

[8] Mok, D.W.S. and Mok, M.C. 2001. Cytokinin metabolism and action. Annu Rev Plant Physiol Plant Mol Biol, 52: 89-118.

[9] Murashige, T. and Skoog, F. 1962. A revised medium for rapid growth and bioassays with tobacco tissue cultures. Plant Physiol., 15: 473-497.

[10] Reddy, Y. M. and Saritha, K.V. 2013. In vitro clonal propagation of Gardenia latifolia Ait.: A toy making woody tree. Agroforest syst, 87: 591-598.

[11] Saha, S., Mori, H. and Hattori, K. 2007. Synergistic effect of kinetin and benzyl adenine plays a vital role in high frequency regeneration from cotyledon explants of bottle gourd (Lagenaria siceraria) in relation to ethylene production. Breeding Sci, 57:197202.

[12] Sharma, N., Chandel, K.P.S. and Anderson, P. 1993. In vitro propagation of Gentiana kurroo - An indigenous threatened plant of medicinal importance. Plant Cell Tissue Organ Cult, 34: 307-309. 
[13] Shekhawat, M. S., Kannan, N., Manokari, M. and Ravindran, C. P. 2015. In vitro regeneration of shoots and ex vitro rooting of an important medicinal plant Passiflora foetida L. through nodal segment cultures. Genet Eng Biotechnol, 13: 209-214.

[14] Shirin, F. and Rana, P. K. 2007. In vitro plantlet regeneration from nodal explants of field- grown culms in Bambusa glaucescens Willd. Plant Biotechnol Rep, 1:141- 147.

[15] Sulaiman, C.T., Geetha, S.P. and Indira, B. 2014. Identification of phenolic antioxidants in Ipomoea mauritiana Jacq. using spectrophotometric and mass spectroscopic studies. Avicenna J Phytomed 4(2): 8996.

[16] Ved, D.K. and Goraya, G. S. 2008. Demand and Supply of Medicinal Plants in India, Bishen Singh Mahendra Pal Singh, Dehradun. India.

[17] Venkatasubramanian, P., Kumar, S. K. and Venugopal, S. N. 2009. Use of 'Kshiravidari' as a substitute for 'Vidri' as per Ayurvedic descriptions. Indian J Tradit Know, 8(3): 310-318.

[18]Zayona, E., Petrova, M., Dimitrova, L., Vasilevska-I. and Stoeva, D. 2014. Effect of different auxins on in vitro rooting of Paulownia elongata Propagated Plants. Genet Plant Physiol, 4 (3-4): 155-162. 